\title{
Variants of PBEF predispose to systemic sclerosis and pulmonary arterial hypertension development
}

\author{
JCA Broen ${ }^{1 *+}$, P Gourh ${ }^{2+}$, M C Vonk ${ }^{1 \dagger}$, L Beretta ${ }^{3}$, F Niederer $^{4}$, B Rueda ${ }^{5}$, L Geurts-van Bon ${ }^{1}$, C Brouwer ${ }^{1}$, \\ R Hesselstrand ${ }^{6}$, A Herrick ${ }^{7}$, J Worthington ${ }^{7}$, N Hunzelman ${ }^{8}$, C Denton ${ }^{9}$, C Fonseca ${ }^{9}$, G Riemekasten ${ }^{10}$, H Kiener ${ }^{11}$, \\ R Scorza ${ }^{3}$, C P Simeon ${ }^{12}$, V Fonollosa ${ }^{12}$, P Carreira ${ }^{13}$, N Ortego-Centeno $^{14}$, M A Gonzalez-Gay $^{15}$, P Airò ${ }^{16}$, \\ MJH Coenen ${ }^{17}$, M Mayes $^{2}$, D Kyburz ${ }^{4}$, F C Arnett ${ }^{2 \dagger}$, J Martin $^{5 \dagger}$, TRDJ Radstake ${ }^{1 \dagger}$
}

From 5th European Workshop on Immune-Mediated Inflammatory Diseases

Sitges-Barcelona, Spain. 1-3 December 2010

\begin{abstract}
Aim
Pre B-cell colony-enhancing factor (PBEF) is intricately involved in inflammation and fibrosis, functional polymorphisms of PBEF have been previously shown to influence PBEF expression and pulmonary damage. Systemic sclerosis ( $\mathrm{SSc}$ ) is a disease in which inflammation, fibrosis and pulmonary deterioration are prominent hallmarks. Therefore we here investigate the role of the $P B E F-1001 T>G$ and $P B E F-1543 C>T$ polymorphisms in the genetic predisposition to systemic sclerosis (SSc) susceptibility and pulmonary involvement.
\end{abstract}

\section{Patients and methods}

We genotyped DNA from 2737 SSc patients and 1913 matched healthy controls, both from 8 different ethnic populations. Genotyping was performed using custom Taqman 5'allelic discrimination assays. In addition, PBEF serum expression levels were measured by ELISA and correlated with genotypes.

\section{Results}

In two separate populations and in a meta-analysis, the combined PBEF -1543CC -1001TT genotype, hence carrying no minor alleles, was found associated with SSc susceptibility $(P=0.009$ OR 1.20 (95\% CI 1.05 -

\footnotetext{
† Contributed equally

${ }^{1}$ Dept. of Rheumatology, Radboud University Nijmegen Medical Center, The Netherlands

Full list of author information is available at the end of the article
}

1.37). In addition, these subjects showed an increased decline in forced vital capacity (FVC) over 15 years follow-up ( $P=0.02)$ (HR 1.64, 95\%CI: 1.02-2.64) and a higher PBEF serum concentration $(P<0.01)$, compared to carriers of minor alleles. On the other hand, patients with genotype $P B E F-1001 T T$ were at lower risk for $\mathrm{PAH}$ development within 15 years of disease onset compared to the carriers with genotypes $P B E F$ 1001GG and PBEF-1001TG $(P<0.001)($ HR 3.29, 95\% CI: $1.52-7.12)$.

\section{Conclusions}

Our data identify PBEF as a novel candidate gene that influences SSc susceptibility, pulmonary function and the development of PAH.

\footnotetext{
Author details

'Dept. of Rheumatology, Radboud University Nijmegen Medical Center, The Netherlands. ${ }^{2}$ Division of Rheumatology and Clinical Immunogenetics, Dept. of Internal Medicine, University of Texas Health Science Center at Houston (UTHSC-H), Houston, TX, USA. ${ }^{3}$ Referral Center for Systemic Autoimmune Diseases, University of Milan, Italy. ${ }^{4}$ University Hospital Zurich Div. of Rheumatology Zurich, Switzerland. Instituto de Parasitología y Biomedicina, CSIC, Granada, Spain. ' $D e p t$. of Rheumatology, Lund University Hospital, Lund, Sweden. 'Rheumatic Diseases Centre, University of Manchester, Salford Royal NHS Foundation Trust, UK. ${ }^{8}$ Dept. of Dermatology, University of Cologne, Germany. ${ }^{9}$ Centre for Rheumatology, Royal Free and University College Medical School, London, UK. ${ }^{10}$ Dept.of Rheumatology and Clinical Immunology, Charité University Hospital and German Rheumatism Research Centre, a Leibniz institute. "1Dept. of Internal Medicine, division of Rheumatology, University of Vienna, Austria. ${ }^{12}$ Servicio de Medicina Interna, Hospital Vall d'Hebron, Barcelona, Spain. ${ }^{13}$ Servicio de Reumatologia, Hospital 12 de Octubre, Madrid, Spain. ${ }^{14}$ Servicio de Medicina Interna, Hospital Clinico Universitario, Granada, Spain. ${ }^{15}$ Servicio de Reumatologia, Hospital Marques de Valdecillas, Santander, Spain. ${ }^{16}$ Servizio di Reumatologia ed Immunologia
} 
Published: 25 November 2010

doi:10.1186/1479-5876-8-S1-P46

Cite this article as: Broen et al:: Variants of PBEF predispose to systemic sclerosis and pulmonary arterial hypertension development. Journal of Translational Medicine 2010 8(Suppl 1):P46.

Submit your next manuscript to BioMed Central and take full advantage of:

- Convenient online submission

- Thorough peer review

- No space constraints or color figure charges

- Immediate publication on acceptance

- Inclusion in PubMed, CAS, Scopus and Google Scholar

- Research which is freely available for redistribution

Submit your manuscript at www.biomedcentral.com/submit
C Biomed Central 